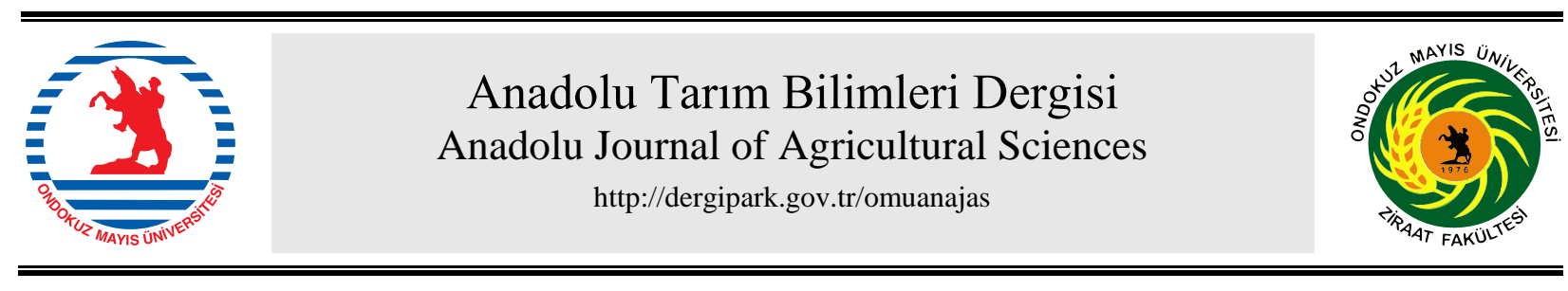

Araştırma/Research

Anadolu Tarım Bilim. Derg./Anadolu J Agr Sci, 33 (2018)

ISSN: 1308-8750 (Print) 1308-8769 (Online)

doi: 10.7161/omuanajas.337798

\title{
Türkiye bal arısı (Apis mellifera L.) alttürlerinde genetik çeşitlilik kaybı
}

\author{
Merve Kambur ${ }^{\mathrm{a}}$, Meral Kekeçoğlu ${ }^{\mathrm{b}, \mathrm{c} *}$ \\ ${ }^{I}$ Düzce Üniversitesi, Fen Bilimleri Ensititüsü, Biyoloji Bölümü, Düzce/Türkiye \\ ${ }^{2}$ Düzce Üniversitesi Fen Edebiyat Fakültesi Biyoloji Bölümü, Düzce/Türkiye \\ ${ }^{2}$ Düzce Üniversitesi Arıcılık Araştırma, Geliştirme ve Uygulama Merkezi (DAGEM), Düzce/Türkiye \\ *Sorumlu yazar/corresponding author: meralkekecoglu@gmail.com
}

Geliş/Received 12/09/2017 Kabul/Accepted 05/02/2018

\begin{abstract}
ÖZET
Son yıllarda yaygın olarak yapılan göçer arıcılık ve ticari ana arı kullanımı nedeniyle Türkiye arı biyoçeşitliliğinde homojenizasyon oluştuğu düşünülmektedir. $\mathrm{Bu}$ nedenle bu çalışma kapsamında Türkiye bal arısı biyoçeşitliliğinin korunup korunamadığı araştırılmıştır. Bu amaçla Türkiye'nin 32 ayrı lokasyonundan işçi arı örnekleri toplandı ve sağ ön kanattaki 19 landmarka göre geometrik morfometrik yöntem kullanılarak çalışıldı. Araştırma bulgularına göre her ne kadar yerel ırkların korunduğu lokal alanlar var olsa da önceki çalışmalarda bildirilen biyoçeşitliliğin (Kuzeyde Apis mellifera caucasica, güneydoğuda $A$. $m$. meda, güneybatıya doğru $A$. $m$. syriaca, Trakya'da A. $m$. carnica, Anadolu'nun geri kalan tüm kesimlerinde ise $A$. $m$. anatoliaca) günümüzde korunamadığı belirlenmiştir. Diskriminant fonksiyon analizi ve UPGMA dendogramı sonuçlarına göre Isparta, Ardahan, Gaziantep, Kahramanmaraş ve Zonguldak populasyonları birbirlerinden ve diğer tüm populasyonlardan ayrı kümelenmişlerdir. Diğer taraftan Kırklareli ve Iğdır ile İzmir, Van ve Hatay ile Hakkari, Antalya, Muğla, Bilecik, Balıkesir ve Çanakkale ile birlikte bir grup oluşturmuştur. Bu çalışmada meydana gelen gruplanmalar önceki literatür bildirişleriyle uyuşmamaktadır. Farklı bölgelerden farklı 1rkları temsil eden örneklerin üst üste çakışması Türkiye arı biyoçeşitliliğinin ticari ana arı kullanım faaliyetlerinden önemli düzeyde etkilendiğini göstermektedir.
\end{abstract}

The loss of genetic diversity on native Turkish honey bee (Apis mellifera L.) subspecies

\begin{abstract}
In recent years it is thought that there has been a homogenization in honeybee biodiversity of Turkey due to the widespread migratory beekeeping and the use of commercial queenbee. Therefore, in the present study it was investigated whether the honey bee biodiversity of Turkey is conserved or not. For this aim worker honey bee samples were taken from 32 different locations of Turkey and the right front wing were studied considering 19 landmarks by using geometric morphometric method. According to research results, although there are local areas within local honeybee races are protected, biodiversity of Turkey which was reported in previous studies (Apis mellifera caucasica in the north, Apis mellifera meda in the south, Apis mellifera syriaca in the southwest, Apis mellifera carnica in Thrace and A. $m$. anatoliaca in rest of Anatolia) has not been protected today. Discriminant function analysis and UPGMA dendograms showed that each of Isparta, Ardahan, Gaziantep, Kahramanmaraş and Zonguldak populations were clustered separately and distiguished from other populations. On the other side, Kirklareli and Igdır formed a group; Izmir, Van and Hatay formed other group, Hakkari, Antalya, Mugla, Bilecik, Balıkesir and Canakkale formed other chorent group. Generated groupings in this study were not incompatible with previous literature reports. Overlapping of samples representing subspecies from different regions showed that honeybee biodiversity in Turkey was significantly affected by the usage activities of commercial queenbee.
\end{abstract}

(C) OMU ANAJAS 2018

Keywords: Apis mellifera $\mathrm{L}$. Honey bee Biodiversity Geometric morphometry

\section{Giriş}

Günümüzde kabul gören 27 bal arısı alttürünü
Anahtar Sözcükler: Apis mellifera $\mathrm{L}$. Bal arıs1 Biyoçeşitlilik Geometrik morfometri kapsayan dört evrimsel kol (O kolu; Kuzeydoğu Akdeniz ve Ortadoğu alttürleri, A kolu; Afrika alttürleri, C kolu; Orta ve Doğu Avrupa alttürleri, M kolu; Batı ve 
Kuzey Avrupa ile Kuzey Afrika alttürleri) bulunmaktadır (Ruttner, 1988; 1992). Türkiye'de var olduğu ifade edilen bal arısı alttürlerinden Apis mellifera anatoliaca, Apis mellifera caucasica, Apis mellifera syriaca, Apis mellifera meda "O" evrimsel kolunda yer alırken, Apis mellifera carnica ise C evrimsel kolunun üyesidir (Ruttner, 1988).

Asya, Avrupa ve Afrika kıtaları arasında bir köprü olan Anadolu, ılıman iklim kuşağında yer almasının yanı sıra farklı coğrafik yapıları bünyesinde barındırmasıyla canlı çeşitliliği bakımından da dikkatleri üzerine çekmektedir. Dolayısıyla Anadolu'daki ekolojik işlevlerin çeşitliliği farklı koşullarda yaşamak üzere evrilmiş farklı canlı türlerini de beraberinde getirmektedir. Kence (2006), Anadolu'nun bu durumunun Türkiye'de yayılış gösteren bal arılarının evrimi üzerinde de etkili olduğunu ifade etmiştir.

Anadolu bal arısı popülasyonlarının dağılım şekillerine ilişkin ilk çalışmalar Butel-Reepen (1906) tarafindan Ege ve Marmara Bölgelerindeki sinırlı alanlarda yürütülmüsşür. Bunu takiben Bodenheimer (1941), Anadolu'da bulunan bal arılarını morfometrik verilere dayalı özelliklerle tanımlamış, bu özelliklere göre ülkeyi 7 ayrı coğrafik bölgeye ayırmıştır. Anadolu arıs1, Apis mellifera anatoliaca'nın ilk taksonomik sınıflandırılması Maa (1953) tarafından yapılmıştır. Daha sonraları Adam (1983) ülkenin kuzeydoğusu, güneydoğusu, batısı ve Anadolu'nun merkezinde olmak üzere 4 belirgin ar1 1rk1 olduğunu ve Anadolu'nun coğrafik konumundan dolayı kapalı ceplerde birçok ekotipin bulunduğunu ifade etmiştir. Anadolu'nun Karadeniz kıyıları ve Akdeniz kıyılarındaki arı popülasyonları arasında morfolojik farklılıklar olduğunu belirtmiştir (Adam 1983). Ruttner (1988), ülkenin kuzeydoğusu (Apis mellifera caucasica) ve güneydoğusu (Apis mellifera meda) hariç, Türkiye' nin Avrupa kısmı da dahil olmak üzere Apis mellifera anatoliaca' nın geniş bir alanda yayıllış gösterdiğini ifade etmiştir. Ruttner (1988)'ın Anadolu'daki bal arısı analizleri ülkenin güneyinde Suriye arısı değil İran arısının baskın olduğunu göstermiştir.

Bal arılarındaki varyasyonu belirlemek için yapılan ilk çalışmalar morfolojik özelliklere dayanmaktadır. Settar (1983), bal arılarında çeşitli vücut parçalarının gerçek ölçümlerini içeren ve bal arılarının varyasyonuna ilişsin çalışmaların 1900'lü yılların başlarında olduğunu ifade etmiştir. Arı ırklarının teşhisinde kullanılan morfolojik özelliklerin, mevcut ırkların belirlenmesinde ve buna bağlı olarak arı irklarının coğrafik dağılımı konusunda önemli olduğunu belirterek bal arılarındaki dil uzunluğunun düzenli bir coğrafik varyasyon gösterdiği ifade edilmiştir. Akabinde devam eden çalışmalarda, morfolojik özelliklere dil uzunluğunun yanı sıra bacak ve kanat uzunluğu, kanat damar açıları, kanattaki kübital indeks değeri, kanattaki çengel sayısı, vücut büyüklüğü, gövde rengi ve k1l yapısı gibi özellikler eklenerek bal arılarının dünyadaki coğrafik varyasyonuna ilişkin tanımlayıcı bilgiler literatüre kazandırılmıştır (Settar, 1983).

Türkiye'de bulunan bal arısı rrklarının çeşitliliğini belirlemek amaciyla morfolojik ölçümlere dayalı tekniklerin yanı sira allozim, mitokondri DNA'sı ve mikrosatellit çalışmaları gibi moleküler teknikler de kullanılarak Anadolu'daki bal arısı çeşitliliği hakkında daha ayrıntılı bilgilere ulaşılmıştır. (Kandemir ve Kence, 1995; Smith ve ark., 1997; Kandemir ve ark., 2000; Özdil ve ark., 2009; Kekeçoğlu ve ark., 2009; Kekeçoğlu ve Soysal, 2010a).

Moleküler ve morfometrik tekniklerin birlikte kullanılmasıyla birlikte ülkemizde 5 ayrı arı irkının (Apis mellifera anatoliaca, Apis mellifera caucasica, Apis mellifera meda, Apis mellifera syriaca, Apis mellifera carnica) varlı̆̆ından söz edilmiștir. Morfometrik karakterler kullanılarak yapılan araştırma sonuçlarına göre Türkiye'de Samsun'dan ülkenin kuzeydoğusuna kadar olan kesiminde Apis mellifera caucasica, güneyde Suriye sınırındaki küçük bir alanda Apis mellifera syriaca, Güneydoğu Anadolu'da Apis mellifera meda, bunlar dışında kalan tüm bölgelerde ise Apis mellifera anatoliaca alttürlerinin yayıllıs gösterdiği bildirilmiştir (Ruttner, 1988; Smith ve ark., 1997; Palmer ve ark., 2000; Kandemir ve ark., 2006a). Trakya bölgesindeki bal arısı popülasyonlarının ise Apis mellifera carnica 1 rkı ile benzerlik gösterdiği belirtilmiştir (Kandemir ve ark., 2000; Kandemir ve ark., 2005; Kekeçoğlu ve Soysal, 2010a; Turan, 2011; Çakmak ve ark., 2014). Bugün hiçbir ülkede bu kadar farklı bal arısı 1rkı bir arada görülmemektedir. $\mathrm{Bu}$ bilimsel gerçekler yalnızca arıcılığın ekonomimize sağlayacağı katkılar nedeniyle değil aynı zamanda ülkemizin kültürel tarihi, ekolojik yapısı ve bilimsel geleceği adına da önemsenmesi gereken gerçeklerdir. Eğer gen kaynaklarımızı koruyamazsak gelecekte sslah ve melezleme çalışmalarında üretim potansiyellerinden yararlanabileceğimiz varyasyon kaynağımız kalmayacaktır. Bugün Ankara keçisi, Van kedisi, Kangal köpeği nasıl Türkiye'nin kültürel tarihini yansıtmak adına önemli bir yere sahipse Anadolu arısı da aynı derecede önemlidir (Kekeçoğlu ve Soysal, 2010a).

Ar1 gibi ekonomik önem arz eden biyolojik canlıların yok olması gıda güvenliğinin geleceği için risk oluşturması bir kenara ülke ekonomisinde de önemli kayıplara yol açacaktır. Bitki zararlılarına karşı pestisitlerle savaşın yaygın olduğu modern tarım koşullarında arı doğal dengenin sağlanmasındaki en önemli silahtır. Entansif üretim alanlarında kaçınılmaz olarak uygulanan tarımsal savaşa karşı bitkisel üretimin güvenceye alınmasını sağlayacak tek faaliyettir.

Özellikle organik tarımın ön plana çıktığı günümüzde doğal bitkisel üretimin sağlanması ve biyolojik dengenin korunmasında bal arılarının önemi göz ardı edilemez. Bu nedenle hayvan genetik kaynaklarında olduğu gibi Türkiye'de doğal olarak bulunan arı gen kaynaklarının tanımlanması ve korunması, biyolojik çeşitliliğin bir unsuru olup insanların gıda ve tarım alanında ihtiyaç duyduğu talebi 
karşılamakta gıda güvencesi, arıcılığın geliştirilmesinde ve islah çalışmalarında hayati önem taşımaktadır. Son günlerde arıcılık alanında çalışan bilim insanları göçer arıc1lık ve ticari ana arı üretimi nedeniyle bal arısı biyoçeşitliliğinin bozulduğundan bahsetmekte ve bu durum büyük kaygı yaratmaktadır. $\mathrm{Bu}$ çalışma günümüzde bal arısı biyoçeşitliliğinin mevcut durumunu koruyup korumadığını belirlemek amacıyla yapılmıştır.

\section{Materyal ve Yöntem}

\subsection{Materyal}

Çalışma materyalimiz olan bal arısının (Apis mellifera L.) örneklemesi Türkiye'deki tüm coğrafik bölgeleri temsil edecek şekilde yapılmıştır. Çalışma, Düzce Üniversitesi Fen Edebiyat Fakültesi Biyoloji Bölümü Moleküler Genetik Araştırma Laboratuvarında yürütülmüştür. Toplamda 252 koloniden örnekleme yapılmıştır. Örnekler 2014-2016 tarihlerinde NisanEylül aylarında toplanmıştır. Örneklerin sabit arıcılık yapılan arılıklardan temin edilmesine özen gösterilmiştir.

Marmara Bölgesi'nde Kırklareli'nden 3, Canakkale, Balıkesir, Bursa ve Bilecik'ten 3; Ege Bölgesi'nde İzmir ve Muğla'dan 3; Akdeniz Bölgesi'nde Antalya, Isparta, Mersin ve Hatay'dan 3, Kahramanmaraş'tan 1; İç Anadolu Bölgesi'nde Kırıkkale ve Konya'dan 3, Niğde ve Eskişehir'den 1; Karadeniz Bölgesi'nde Sakarya'dan 2, Düzce, Sinop, Zonguldak, Amasya, Ordu, Trabzon ve Artvin'den 3, Kastamonu' dan 4; Doğu Anadolu Bölgesi'nde Ardahan, Kars, Iğdır ve Bingöl' den 3, Hakkâri ve Van'dan 1; Güneydoğu Anadolu Bölgesi'nde Gaziantep'ten 4 arllık olmak üzere toplamda 84 arılıktan örnek alınmıştır. 84 arılığın her birinden 3'er koloni olmak üzere toplam 252 koloni ve her koloniden en az 15, en çok 30 adet işçi arı olmak üzere toplamda 4320 işçi arı örneği alınmıştır. Her bir işçi arı örneğinin sağ ön kanadı çalışma materyalini oluşturmuştur. Hasarlı kanatlar ölçümlerin dışında bırakılmıştır ve 4076 işçi arı örneği analizlere dâhil edilmiștir. Bu çalıșmada Türkiye'de yayılıș gösteren bal arısı popülasyonları geometrik morfometri yöntemiyle analiz edilmiştir.

\subsection{Yöntem}

Örneklerin taşınması, muhafazası ve preparat hazırlama Kekeçoğlu (2007)'na göre yapılmıştır. Hazırlanan preparatların fotoğrafları BAB STR45 stereozoom mikroskobuna bağlı $\mathrm{BAB}$ kamera sistemiyle $1 \mathrm{X}$ büyütmede çekilmiştir.

Geometrik morfometrik yönteme göre kanatlarda 19 landmark işaretlemesi yapılmıştır (Kambur, 2017). İşaretlenen landmarkların kartezyen koordinatların (X, Y) ölçümü BAB Bs200ProP programında otomatik olarak yapılmıştır. Morfometrik ölçümleri yapılan kanat karakterlerine ilişkin ham veriler SPSS.15 paket programında Diskriminant Fonksiyon Analizi (DFA) ile değerlendirilmiştir. Grup içi ve gruplar arası varyasyonun belirlenmesinde grupları ayırmada tüm karakterlerin aynı anda kullanıldı̆̆ı çok değişkenli varyans analizi (MANOVA) uygulanmıştır. Kanat verilerine göre popülasyonların gruplara dağılımlarını görmek için Cross Validation Test (CVT) - Çapraz Doğrulama Testi yapılmış ve örneklerin gruplara dağılımı belirlenmiştir.

\section{Bulgular}

Bu araştırmada Türkiye' de yayılış gösteren bal arısı popülasyonlarının geometrik morfometri yöntemiyle analizi gerçekleştirilmiştir. Böceklerde uçma aktiviteleri için önemli olan ve değişmez bir yapıya sahip olan kanatlar, bal arısı alttürlerinin de ayırt edilmesinde önemli morfometrik karakterleri üzerinde taşımasından dolayı kanatlarla çalışılmışıtır.

Çalışma kapsamında popülasyonların 19 landmarka ait kartezyen koordinatlarının genel ortalamaları, standart hataları, minimum ve maksimum değerleri incelenmiştir. Bireylerin çok boyutlu ortamda gruplara dağılımlarını belirlemede diskriminant fonksiyon analizinden yararlanılmıştır. Popülasyonların sınıflandırılmalarını sağlayan diskriminant fonksiyonları 19 landmarkın kartezyen koordinat değerlerine göre belirlenmiştir. Analize giren fonksiyon saylları, bu fonksiyonların önem düzeyleri, öz değerleri (eigen), varyasyon yüzdeleri (\%), kümülatif değerleri (\%), kanonik korelasyon değerleri, Wilk's lambda, ki kare değerleri ile serbestlik dereceleri Çizelge 1'de verilmiştir.

Çizelge 1 incelendiğinde kartezyen koordinat verilerine göre analize giren 31 fonksiyondan 27'si önemli bulunmuştur $(\mathrm{P}<0.05)$. Fonksiyonlara göre varyasyon yüzdelerine bakıldığında, analize giren ilk iki fonksiyonun değeri sirasiyla \% 70.4 ve \% 23.2'dir. Bu iki fonksiyon toplam varyasyonun \% 93.6'sını açıklamaktadır.

Her değişken ile herhangi bir diskriminant fonksiyonu arasındaki kanonik korelasyon katsayılarının bulunduğu yap1 matrisi incelendiğinde en yüksek kanonik korelasyona sahip olan karakterlerin; birinci fonksiyonda Y14, Y15, Y16; ikinci fonksiyonda Y0, Y5, Y6, Y1, Y8, Y2, Y4, Y7; üçüncü fonksiyonda X0, $\mathrm{X} 1, \mathrm{X} 2, \mathrm{X} 3, \mathrm{X} 4, \mathrm{X} 5, \mathrm{X} 6, \mathrm{X} 8, \mathrm{X} 10, \mathrm{X} 7, \mathrm{X} 11, \mathrm{X} 9, \mathrm{X} 12$, $\mathrm{X} 13, \mathrm{X} 18, \mathrm{X} 17, \mathrm{X} 15, \mathrm{X} 14$; dördüncü fonksiyonda X16, Y13, Y12, X3; on ikinci fonksiyonda Y18; on üçüncü fonksiyonda ise Y10, Y17, Y11 olduğu belirlenmiştir.

Popülasyonları temsil eden arı örneklerinin bireysel verileri (38 kartezyen koordinatı) MANOVA ile karşılaş̧ırıldığında en az bir karakter bakımından tüm illerin birbirinden farklılığı önemli $\quad(\mathrm{P}<0.05)$ bulunmuştur.

Bireysel verilerin kullanıldığı diskriminant analizi sonucuna göre gerçek gruplara doğru sınıflandırma oranı \% 97.3 olarak bulunmuştur. Dolayısıyla bireylerin çoğu gözlemle belirlenen ait oldukları gruba 
girmişlerdir. Grup üyeliği \% 100 olan bölgeler Kastamonu, Sinop, Artvin, Ardahan, Gaziantep, Hatay ve Isparta'dır (Çizelge 2). Bu çalışmanın materyalini oluşturan Türkiye bal arısı örneklerinin geometrik morfometrik yönteme göre kendi içerisinde dağılımını incelemek amaciyla ilk iki diskriminant fonksiyonu ile iki boyutlu serpilme diyagramı çizilmiştir. Popülasyonların ayrılmasında etkili olan bu iki fonksiyondan ilki toplam varyasyonun \% 70.4'ünü ikinci fonksiyon ise \% 23.2'sini açıklamaktadır. Şekil 1 'de görüldügü üzere farklı bölgeleri temsil eden illerin grup merkezleri arasında çakışmalar ve iç içe geçmeler olmuştur. Şekil 1 incelendiğinde; Gaziantep, Zonguldak ve Kahramanmaraş örnekleri diğer illerden ve birbirlerinden uzakta ayrı kümeler oluşturmuştur.

Niğde ile Eskişehir, Sakarya ile Ordu, Hakkâri ile Muğla, Balıkesir ile Çanakkale, Amasya ile Kırıkkale, Konya ve Mersin örneklerinin grup merkezleri birbirleriyle çakışmıştır. Ardahan ve Isparta örneklerinin grup merkezleri Sakarya-Ordu grubuna yakın fakat birbirlerinden ayrı kümelenmişlerdir. Hatay, Van ve İzmir örneklerinin grup merkezleri birbirine yakın kümelenmiştir. Ayrıca Hatay ve Van örneklerinin bir kısmı iç içe geçmiştir. Balıkesir ve Çanakkale örnekleri ile Antalya örnekleri birbirine çok yakın kümelenmiş ve kısmen iç içe geçmiştir. Bilecik örnekleri grup merkezleri çakışan Hakkâri-Muğla grubu ile yakın kümelenmiştir.

Çizelge 1. Populasyonların belirlenen fonksiyon sayıları ve bu fonksiyonları ifade eden değerler

\begin{tabular}{|l|c|c|c|c|c|c|c|c|}
\hline $\begin{array}{l}\text { Fonksiyon } \\
\text { sayısı }\end{array}$ & Özdeğer & $\begin{array}{c}\text { Varyasyon } \\
\text { değeri (\%) }\end{array}$ & $\begin{array}{c}\text { Kümülatif } \\
\text { değeri (\%) }\end{array}$ & $\begin{array}{c}\text { Kanonikal } \\
\text { korelasyon }\end{array}$ & $\begin{array}{c}\text { Wilks' } \\
\text { Lambda }\end{array}$ & Ki-kare & df & $\begin{array}{c}\text { Önem } \\
\text { düzeyi (P) }\end{array}$ \\
\hline 1 & 102.799 & 70.4 & 70.4 & 0.995 & 0 & 51220.91 & 1116 & $0^{*}$ \\
\hline 2 & 33.812 & 23.2 & 93.6 & 0.986 & 0 & 32446.8 & 1050 & $0^{*}$ \\
\hline 3 & 6.642 & 4.6 & 98.1 & 0.932 & 0.011 & 18090.79 & 986 & $0^{*}$ \\
\hline 4 & 0.515 & 0.4 & 98.5 & 0.583 & 0.087 & 9866.877 & 924 & $0^{*}$ \\
\hline 5 & 0.341 & 0.2 & 98.7 & 0.504 & 0.132 & 8186.88 & 864 & $0^{*}$ \\
\hline 6 & 0.266 & 0.2 & 98.9 & 0.459 & 0.177 & 6999.974 & 806 & $0^{*}$ \\
\hline 7 & 0.201 & 0.1 & 99.1 & 0.409 & 0.224 & 6045.18 & 750 & $0^{*}$ \\
\hline 8 & 0.187 & 0.1 & 99.2 & 0.397 & 0.269 & 5304.492 & 696 & $0^{*}$ \\
\hline 9 & 0.178 & 0.1 & 99.3 & 0.389 & 0.32 & 4611.51 & 644 & $0^{*}$ \\
\hline 10 & 0.152 & 0.1 & 99.4 & 0.363 & 0.377 & 3948.627 & 594 & $0^{*}$ \\
\hline 11 & 0.123 & 0.1 & 99.5 & 0.331 & 0.434 & 3377.382 & 546 & $0^{*}$ \\
\hline 12 & 0.111 & 0.1 & 99.6 & 0.316 & 0.487 & 2908.118 & 500 & $0^{*}$ \\
\hline 13 & 0.104 & 0.1 & 99.6 & 0.307 & 0.541 & 2481.993 & 456 & $0^{*}$ \\
\hline 14 & 0.091 & 0.1 & 99.7 & 0.288 & 0.598 & 2081.546 & 414 & $0^{*}$ \\
\hline 15 & 0.081 & 0.1 & 99.8 & 0.274 & 0.652 & 1730.982 & 374 & $0^{*}$ \\
\hline 16 & 0.069 & 0 & 99.8 & 0.254 & 0.705 & 1415.799 & 336 & $0^{*}$ \\
\hline 17 & 0.058 & 0 & 99.8 & 0.234 & 0.753 & 1147.108 & 300 & $0^{*}$ \\
\hline 18 & 0.046 & 0 & 99.9 & 0.209 & 0.797 & 918.955 & 266 & $0^{*}$ \\
\hline 19 & 0.039 & 0 & 99.9 & 0.195 & 0.833 & 739.016 & 234 & $0^{*}$ \\
\hline 20 & 0.033 & 0 & 99.9 & 0.178 & 0.866 & 582.524 & 204 & $0^{*}$ \\
\hline 21 & 0.026 & 0 & 99.9 & 0.158 & 0.894 & 453.05 & 176 & $0^{*}$ \\
\hline 22 & 0.021 & 0 & 100 & 0.144 & 0.917 & 350.88 & 150 & $0^{*}$ \\
\hline 23 & 0.018 & 0 & 100 & 0.135 & 0.936 & 266.719 & 126 & $0^{*}$ \\
\hline 24 & 0.011 & 0 & 100 & 0.106 & 0.953 & 192.745 & 104 & $0^{*}$ \\
\hline 25 & 0.011 & 0 & 100 & 0.102 & 0.964 & 146.89 & 84 & $0^{*}$ \\
\hline 26 & 0.009 & 0 & 100 & 0.092 & 0.975 & 104.338 & 66 & $0.002^{*}$ \\
\hline 27 & 0.006 & 0 & 100 & 0.079 & 0.983 & 70.067 & 50 & $0.032^{*}$ \\
\hline 28 & 0.005 & 0 & 100 & 0.07 & 0.989 & 44.552 & 36 & 0.155 \\
\hline 29 & 0.003 & 0 & 100 & 0.057 & 0.994 & 24.84 & 24 & 0.415 \\
\hline 30 & 0.002 & 0 & 100 & 0.044 & 0.997 & 11.595 & 14 & 0.639 \\
\hline 31 & 0.001 & 0 & 100 & 0.03 & 0.999 & 3.618 & 6 & 0.728 \\
\hline
\end{tabular}

Düzce ve Bursa kısmen iç içe geçmiş ve SakaryaOrdu grubu ile birbirlerine yakın kümelenmişlerdir. Artvin örnekleri Sakarya-Ordu grubu ile BalıkesirÇanakkale grupları arasında ve her iki gruba yakın kümelenmiştir. Kars örnekleri, Amasya-KırıkkaleKonya-Mersin grubuyla iç içe geçmiştir fakat grup merkezleri çakışmamıştır. Iğdır, Mersin ve Bingöl örnekleri iç içe geçmiştir fakat grup merkezleri birbirleriyle çakışmamıştır. Iğdır, Kırklareli ve Kastamonu örneklerin iç içe geçmiştir. Trabzon örnekleri Niğde ve Kastamonu örnekleri ile yakın kümelenmiştir. Sinop örnekleri Niğde-Eskişehir grubu ile yakın fakat onlardan ayrı kümelenmiştir. Grupların birbirlerine olan uzaklıkları UPGMA metoduna göre 
çizilen dendogramda gösterilmiş̧ir (Şekil 2). Mahalonobis uzaklıklarına göre çizilen dendogramda Sakarya, Ordu, Artvin, Düzce, Bursa popülasyonları ile Hakkâri, Muğla, Bilecik, Balıkesir ve Antalya popülasyonları birlikte bir grup oluşturmuştur. Kastamonu, Eskişehir, Niğde popülasyonları ile Amasya, Kars, Mersin, Bingöl, Kırıkkale, Konya, Iğdır,
Kırklareli ve Trabzon popülasyonları birlikte bir grup oluştururken, Van, İzmir ve Hatay popülasyonları birlikte diğer bir grubu oluşturmuştur. Ardahan, Isparta ve Gaziantep ile Zonguldak, Sinop ve Kahramanmaraş popülasyonları diğer popülasyonlardan ayrılarak iki ayrı grup oluşturmuşlardır.

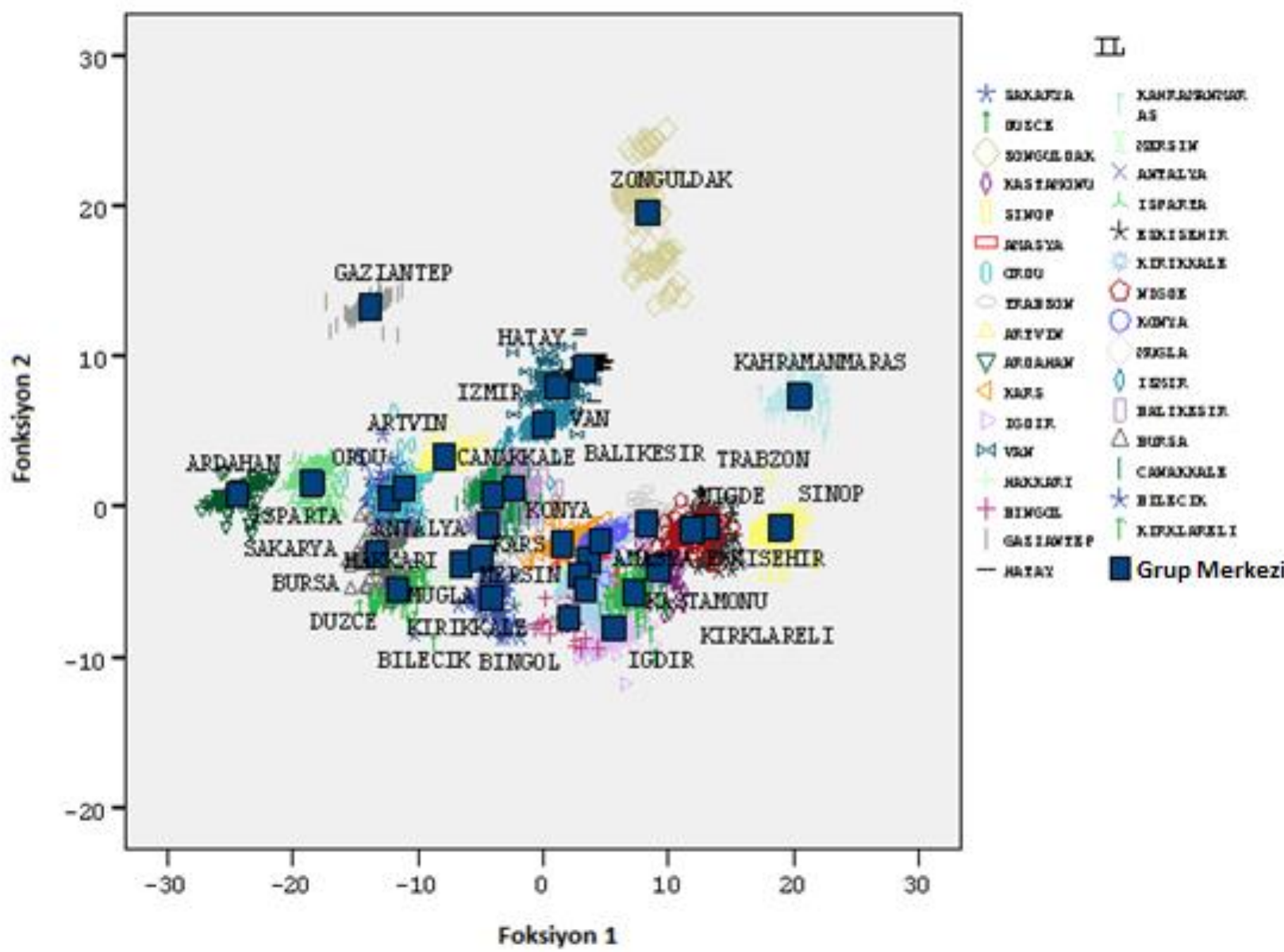

Şekil 1. Popülasyonların ayrışım fonksiyon analizi (DFA) ile iki boyutlu kümelenmesi

\section{Tartıșma}

Geçmiş yıllarda organizmaların sınıflandırılması amaciyla kullanılan standart morfometrik yöntem manuel olarak yapılmaktaydı. Zaman ve iş gücü gerektiren bu yöntemin bir dezavantaj1 da tekrarlanan her doğrusal ölçümde hata payının yüksek olması ve farklı şekillerde homolog noktalar arasındaki ölçümler ile şekillerin karşılaştırmasını zorlaştırmasıdır. Bilgisayar teknolojisinin gelişmesiyle birlikte araştırmacılar yoğun iş gücü ve zaman gerektiren bu yönteme alternatif yöntemler geliştirmeye çalışmıştır (Adams ve ark., 2004; Adams ve ark., 2013). Bal arıs1 popülasyonlarını ayırt etmek için de zaman içerisinde standart morfometri yönteminden geometrik morfometrik yöntemine doğru bir geçiş olmuştur (Tofilski, 2008; Turan, 2011; Koca ve Kandemir, 2013). Tofilski (2008), Apis mellifera mellifera, Apis mellifera carnica ve Apis mellifera caucaasica alttürleri ile yaptığı çalışmasında geometrik morfometri yönteminin bu üç alt türü ayırmada standart morfometriye göre daha iyi ayrım sağladığını ifade etmiștir. Ortadoğu'da yayılıș gösteren bal arıları geometrik morfometri yöntemiyle analiz edilmiş ve bu yöntemin bal arısı alttürlerini ayırmada daha güvenilir olduğunu vurgulamıștır (Koca ve Kandemir, 2013). 


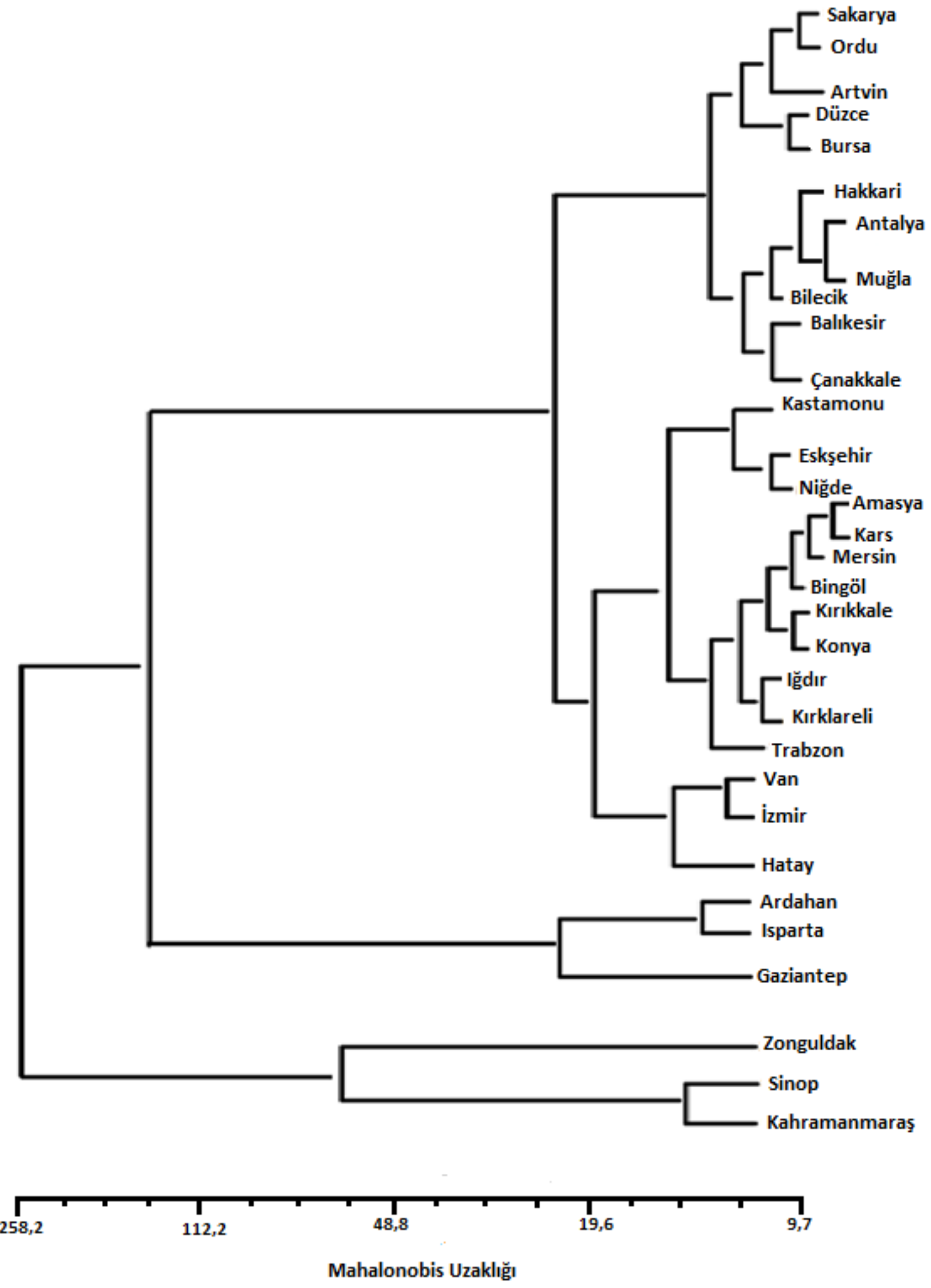

Şekil 2. Analiz edilen popülasyonların UPGMA fenogramı 


\section{Çizelge 2. Çapraz doğrulama testi (CVT)'ne göre illeri temsil eden örneklerin gruplandırılması}

\begin{tabular}{|c|c|c|c|c|c|c|c|c|c|c|c|c|c|c|c|c|c|c|c|c|c|c|c|c|c|c|c|c|c|c|c|c|c|}
\hline & \multicolumn{33}{|c|}{ Tahmin Edilen Grup Üyeliği } \\
\hline İL & 1 & 2 & 3 & 4 & 5 & 6 & 7 & 8 & 9 & 10 & 11 & 12 & 13 & 14 & 15 & 16 & 17 & 18 & 19 & 20 & 21 & 22 & 23 & 24 & 25 & 26 & 27 & 28 & 29 & 30 & 31 & 32 & Total \\
\hline 1 & 130 & 0 & 0 & 0 & 0 & 0 & 4 & 0 & 0 & 0 & 0 & 0 & 0 & 0 & 0 & 0 & 0 & 0 & 0 & 0 & 0 & 0 & 0 & 0 & 0 & 0 & 0 & 0 & 0 & 0 & 0 & 0 & 134 \\
\hline 2 & 0 & 129 & 0 & 0 & 0 & 0 & 0 & 0 & 0 & 0 & 0 & 0 & 0 & 1 & 0 & 0 & 0 & 0 & 0 & 0 & 0 & 0 & 0 & 0 & 0 & 0 & 0 & 0 & 5 & 0 & 0 & 0 & 135 \\
\hline 3 & 0 & 0 & 122 & 0 & 0 & 0 & 0 & 0 & 0 & 0 & 0 & 0 & 0 & 0 & 0 & 0 & 1 & 0 & 0 & 0 & 0 & 0 & 0 & 0 & 0 & 0 & 0 & 0 & 0 & 0 & 0 & 0 & 123 \\
\hline 4 & 0 & 0 & 0 & 223 & 0 & 0 & 0 & 0 & 0 & 0 & 0 & 0 & 0 & 0 & 0 & 0 & 0 & 0 & 0 & 0 & 0 & 0 & 0 & 0 & 0 & 0 & 0 & 0 & 0 & 0 & 0 & 0 & 223 \\
\hline 5 & 0 & 0 & 0 & 0 & 117 & 0 & 0 & 0 & 0 & 0 & 0 & 0 & 0 & 0 & 0 & 0 & 0 & 0 & 0 & 0 & 0 & 0 & 0 & 0 & 0 & 0 & 0 & 0 & 0 & 0 & 0 & 0 & 117 \\
\hline 6 & 0 & 0 & 0 & 0 & 0 & 130 & 0 & 0 & 0 & 0 & 1 & 0 & 0 & 0 & 1 & 0 & 0 & 0 & 2 & 0 & 0 & 0 & 0 & 0 & 0 & 0 & 0 & 0 & 0 & 0 & 0 & 0 & 134 \\
\hline 7 & 10 & 0 & 0 & 0 & 0 & 0 & 122 & 0 & 0 & 0 & 0 & 0 & 0 & 0 & 0 & 0 & 0 & 0 & 0 & 0 & 0 & 0 & 0 & 0 & 0 & 0 & 0 & 0 & 0 & 0 & 0 & 0 & 132 \\
\hline 8 & 0 & 0 & 0 & 2 & 0 & 1 & 0 & 130 & 0 & 0 & 0 & 0 & 0 & 0 & 0 & 0 & 0 & 0 & 0 & 0 & 0 & 0 & 0 & 0 & 0 & 0 & 0 & 0 & 0 & 0 & 0 & 1 & 134 \\
\hline 9 & 0 & 0 & 0 & 0 & 0 & 0 & 0 & 0 & 135 & 0 & 0 & 0 & 0 & 0 & 0 & 0 & 0 & 0 & 0 & 0 & 0 & 0 & 0 & 0 & 0 & 0 & 0 & 0 & 0 & 0 & 0 & 0 & 135 \\
\hline 10 & 0 & 0 & 0 & 0 & 0 & 0 & 0 & 0 & 0 & 124 & 0 & 0 & 0 & 0 & 0 & 0 & 0 & 0 & 0 & 0 & 0 & 0 & 0 & 0 & 0 & 0 & 0 & 0 & 0 & 0 & 0 & 0 & 124 \\
\hline 11 & 0 & 0 & 0 & 0 & 0 & 5 & 0 & 0 & 0 & 0 & 124 & 0 & 0 & 0 & 0 & 0 & 0 & 0 & 1 & 0 & 0 & 0 & 0 & 0 & 1 & 1 & 0 & 0 & 0 & 0 & 0 & 0 & 132 \\
\hline 12 & 0 & 0 & 0 & 2 & 0 & 0 & 0 & 0 & 0 & 0 & 0 & 122 & 0 & 0 & 1 & 0 & 0 & 0 & 5 & 0 & 0 & 0 & 0 & 0 & 0 & 0 & 0 & 0 & 0 & 0 & 0 & 0 & 130 \\
\hline 13 & 0 & 0 & 0 & 0 & 0 & 0 & 0 & 0 & 1 & 0 & 0 & 0 & 120 & 0 & 0 & 0 & 11 & 0 & 0 & 0 & 0 & 0 & 0 & 0 & 0 & 0 & 5 & 1 & 0 & 0 & 0 & 0 & 138 \\
\hline 14 & 0 & 0 & 0 & 0 & 0 & 0 & 1 & 0 & 0 & 0 & 0 & 0 & 0 & 70 & 0 & 0 & 0 & 0 & 0 & 0 & 0 & 0 & 0 & 0 & 0 & 3 & 0 & 0 & 0 & 0 & 0 & 0 & 74 \\
\hline 15 & 0 & 0 & 0 & 0 & 0 & 0 & 0 & 0 & 0 & 0 & 0 & 1 & 0 & 0 & 49 & 0 & 0 & 0 & 0 & 0 & 0 & 0 & 0 & 0 & 0 & 0 & 0 & 0 & 0 & 0 & 0 & 0 & 50 \\
\hline 16 & 0 & 0 & 0 & 0 & 0 & 0 & 0 & 0 & 0 & 0 & 0 & 0 & 0 & 0 & 0 & 86 & 0 & 0 & 0 & 0 & 0 & 0 & 0 & 0 & 0 & 0 & 0 & 0 & 0 & 0 & 0 & 0 & 86 \\
\hline 17 & 0 & 0 & 0 & 0 & 0 & 0 & 0 & 0 & 0 & 0 & 0 & 0 & 0 & 0 & 0 & 0 & 135 & 0 & 0 & 0 & 0 & 0 & 0 & 0 & 0 & 0 & 0 & 0 & 0 & 0 & 0 & 0 & 135 \\
\hline 18 & 0 & 0 & 0 & 0 & 0 & 0 & 0 & 0 & 0 & 0 & 0 & 0 & 0 & 0 & 0 & 0 & 0 & 108 & 0 & 0 & 0 & 0 & 0 & 1 & 0 & 0 & 0 & 0 & 0 & 0 & 0 & 0 & 109 \\
\hline 19 & 0 & 0 & 0 & 0 & 0 & 0 & 0 & 0 & 0 & 0 & 0 & 0 & 0 & 0 & 0 & 0 & 0 & 0 & 133 & 0 & 0 & 0 & 0 & 0 & 0 & 0 & 0 & 0 & 0 & 0 & 1 & 1 & 135 \\
\hline 20 & 0 & 0 & 0 & 0 & 0 & 0 & 0 & 0 & 0 & 0 & 0 & 0 & 0 & 0 & 0 & 0 & 0 & 0 & 0 & 127 & 0 & 0 & 0 & 0 & 0 & 6 & 0 & 1 & 0 & 1 & 0 & 0 & 135 \\
\hline 21 & 0 & 0 & 0 & 0 & 0 & 0 & 0 & 0 & 0 & 0 & 0 & 0 & 0 & 0 & 0 & 0 & 0 & 0 & 0 & 0 & 128 & 0 & 0 & 0 & 0 & 0 & 0 & 0 & 0 & 0 & 0 & 0 & 128 \\
\hline 22 & 0 & 0 & 0 & 0 & 0 & 0 & 0 & 0 & 0 & 0 & 0 & 0 & 0 & 0 & 0 & 0 & 0 & 0 & 0 & 0 & 0 & 128 & 0 & 2 & 0 & 0 & 0 & 0 & 0 & 0 & 0 & 0 & 130 \\
\hline 23 & 0 & 0 & 0 & 0 & 0 & 0 & 0 & 0 & 0 & 0 & 0 & 2 & 0 & 0 & 0 & 0 & 0 & 0 & 1 & 0 & 0 & 0 & 131 & 0 & 1 & 0 & 0 & 0 & 0 & 0 & 0 & 0 & 135 \\
\hline
\end{tabular}


Çizelge 2 (devam). Çapraz doğrulama testi (CVT)'ne göre illeri temsil eden örneklerin gruplandırılması

\begin{tabular}{|c|c|c|c|c|c|c|c|c|c|c|c|c|c|c|c|c|c|c|c|c|c|c|c|c|c|c|c|c|c|c|c|c|c|}
\hline & \multicolumn{33}{|c|}{ Tahmin Edilen Grup Üyeliği } \\
\hline íL & 1 & 2 & 3 & 4 & 5 & 6 & 7 & 8 & 9 & 10 & 11 & 12 & 13 & 14 & 15 & 16 & 17 & 18 & 19 & 20 & 21 & 22 & 23 & 24 & 25 & 26 & 27 & 28 & 29 & 30 & 31 & 32 & Total \\
\hline 24 & 0 & 0 & 0 & 1 & 0 & 0 & 0 & 0 & 0 & 0 & 0 & 0 & 0 & 0 & 0 & 0 & 0 & 0 & 0 & 0 & 0 & 2 & 0 & 130 & 0 & 0 & 0 & 0 & 0 & 0 & 0 & 0 & 133 \\
\hline 25 & 0 & 0 & 0 & 0 & 0 & 0 & 0 & 0 & 0 & 0 & 0 & 0 & 0 & 0 & 0 & 0 & 0 & 0 & 0 & 0 & 0 & 0 & 1 & 0 & 133 & 0 & 0 & 0 & 0 & 0 & 0 & 0 & 134 \\
\hline 26 & 0 & 0 & 0 & 0 & 0 & 0 & 0 & 0 & 0 & 0 & 0 & 0 & 0 & 1 & 0 & 0 & 0 & 0 & 0 & 4 & 0 & 0 & 0 & 0 & 0 & 115 & 0 & 0 & 0 & 0 & 3 & 0 & 123 \\
\hline 27 & 0 & 0 & 0 & 0 & 0 & 0 & 0 & 0 & 0 & 0 & 0 & 0 & 0 & 0 & 0 & 0 & 0 & 0 & 0 & 0 & 0 & 0 & 0 & 0 & 0 & 0 & 128 & 1 & 0 & 0 & 0 & 0 & 129 \\
\hline 28 & 0 & 0 & 0 & 0 & 0 & 0 & 0 & 0 & 0 & 0 & 1 & 0 & 0 & 0 & 0 & 0 & 0 & 0 & 0 & 0 & 0 & 0 & 0 & 0 & 0 & 0 & 0 & 133 & 0 & 0 & 0 & 0 & 134 \\
\hline 29 & 1 & 0 & 0 & 0 & 0 & 0 & 0 & 0 & 0 & 0 & 0 & 0 & 0 & 0 & 0 & 0 & 0 & 0 & 0 & 0 & 0 & 0 & 0 & 0 & 0 & 0 & 0 & 0 & 121 & 0 & 0 & 0 & 122 \\
\hline 30 & 0 & 0 & 0 & 0 & 0 & 0 & 0 & 0 & 0 & 0 & 0 & 0 & 0 & 0 & 0 & 0 & 0 & 0 & 0 & 1 & 0 & 0 & 0 & 0 & 0 & 0 & 0 & 0 & 0 & 133 & 0 & 0 & 134 \\
\hline 31 & 0 & 1 & 0 & 0 & 0 & 0 & 0 & 0 & 0 & 0 & 0 & 0 & 0 & 0 & 0 & 0 & 0 & 0 & 0 & 1 & 0 & 0 & 0 & 0 & 0 & 3 & 0 & 0 & 0 & 0 & 128 & 0 & 133 \\
\hline 32 & 0 & 0 & 0 & 2 & 0 & 0 & 0 & 0 & 0 & 0 & 0 & 2 & 0 & 0 & 0 & 0 & 0 & 0 & 0 & 0 & 0 & 0 & 0 & 0 & 1 & 0 & 0 & 0 & 0 & 0 & 0 & 124 & 129 \\
\hline
\end{tabular}

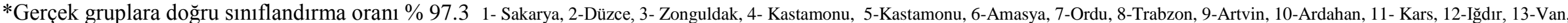

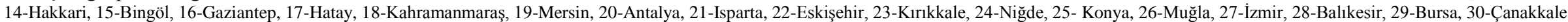

31-Bilecik, 32-Kırklareli. 
Morfometrik karakterler kullanılarak yapilan araştırmalarda, Türkiye'de Samsun'dan ülkenin kuzeydoğusuna kadar olan kesiminde Apis mellifera caucasica, güneyde Suriye sınırındaki küçük bir alanda Apis mellifera syriaca, Güneydoğu Anadolu'da Apis mellifera meda ve bunlar dışında kalan tüm bölgelerde ise Apis mellifera anatoliaca alttürlerinin yayılış gösterdiği bildirilmiştir (Ruttner, 1988). Ayrıca Trakya bölgesindeki bal arısı populasyonlarının Apis mellifera carnica 1rkı ile benzerlik gösterdiğini ifade eden literatür de mevcuttur (Kandemir ve ark., 2000; Kandemir ve ark., 2005; Turan, 2011; Çakmak ve ark., 2014).

Anadolu bal arısı biyoçeşitliliği ilk kez Marmara ve Ege Bölgesi'ni kapsayan küçük bir alanda çalışılmış ve 7 coğrafik zon tanımlanmıştır (Buttel-Reepen, 1906; Bodenheimer, 1941). Anadolu arıs1 (Apis mellifera anatoliaca) için ilk taksonomik sınıflandırma morfometrik verilere dayanılarak Maa tarafindan yapılmıştır (Maa, 1953). Daha sonra Anadolu arısı ile ilgili çalışmalar Adam (1983) tarafından sürdürülmüştür. Adam (1983) Anadolu'da 4 alttür ve birçok ekotip olduğundan söz etmiştir. Özellikle Karadeniz ve Akdeniz Bölgelerinde tamamiyla birbirinden farklı irklar bulunduğunu ve güneyde Apis mellifera syriaca olduğunu vurgulamıştır. Fakat Ruttner (1988) kuzeydoğuda Apis mellifera caucasica, güneyde Apis mellifera meda Anadolu'nun geri kalan kısımlarında ise Apis mellifera anatoliaca olduğunu bildirmiştir. Özbakır (2011) çalışmasında Hatay grubunun Suriye grupları arasında serpilme gösterdiğini dolayısiyla Hatay'da bulunan bal arıs1 popülasyonlarının Apis mellifera syriaca olabileceğini belirtmiştir. Ayrıca Van ve Hakkâri gruplarının da Apis mellifera meda ile benzerlik gösterdiğini vurgulamıştır.

$\mathrm{Bu}$ çalışma kapsamında elde edilen sonuçların yukarıdaki literatür bildirişleri ile karşıllaştırılması için Türkiye'nin 7 farklı coğrafik bölgesini temsil eden illerden örnekleme yapılmıştır.

$\mathrm{Bu}$ çalışmada bireysel veriler esas alınarak yapılan diskriminant analiz sonuçlarına göre bireylerin kendi gruplarına doğru sınıflandırma oranı \% 97.3'tür. Grup üyeliği \% 100 olan iller Kastamonu, Sinop, Artvin, Ardahan, Gaziantep ve Hatay olarak belirlenmiştir. Kastamonu ve Sinop illeri için bu sonuç örnek temini sırasında arıcılara yöneltilen anket sorularından "Göçer arıcılık yapıyor musunuz?" sorusuna verdikleri "Hayır." cevabını doğrular niteliktedir. Güler ve Toy (2008) Sinop ve çevresinde bulunan arı popülasyonlarının saf olmadığını bildirmişlerdir. Ancak bizim çalışmamızda iller bazında geometrik morfometri yöntemine göre yapılan CVT sonucunda Sinop ilinden alınan örnekler $\% 100$ kendi grubunda kalmıştır.

Uzunluk ve açı ölçümüne dayanan morfometrik yöntem kullanılarak Türkiye'deki bal arısı alttürlerini tanımlamaya yönelik çalışmalarda Türkiye'nin kuzeydoğusunda Apis mellifera caucasica olduğu bildirilmektedir (Ruttner, 1988; Kandemir ve ark., 2000; Güler ve Bek, 2002; Kandemir ve ark., 2005).
Türkiye'nin kuzey kıyısı boyunca yayılış gösteren bal arıs1 alttürlerinin Apis mellifera anatoliaca veya bu alttürün bir ekotipi olduğunu belirten çalışmalar da mevcuttur (Kandemir ve ark., 2000; Kekeçoğlu, 2007; Kekeçoğlu ve Soysal, 2010b; Çakmak ve ark., 2014). $\mathrm{Bu}$ çalışmada yapılan kanonikal varyans analizinde Kastamonu, Sinop ve Artvin illerinin ayrı şekilde kümelenmeleri Türkiye'nin kuzey kıyısı boyunca Apis mellifera caucasica dışında da arı 1rk veya varyeteleri olabileceğini işaret etmektedir. Aynı zamanda kanonikal varyans analizine göre çizilen iki boyutlu grafikte ve UPGMA dendogramında Artvin ve Ordu birlikte bir grup oluştururken Ardahan ve Trabzon birbirinden bağımsız ayrı gruplar oluşturmuştur. Bu sonuçlara göre Türkiye'nin kuzeydoğusundaki her ilde Apis mellifera caucasica bulunduğunu söylemek güçleşmektedir. Batı Karadeniz Bölgesi'ni temsil eden bu iller için Güler ve ark., (2013) tarafindan yapılan bir çalışmada Batı Karadeniz bal arısı popülasyonlarının Anadolu arı biyoçeşitliliğinin bir parçası olması nedeniyle bu bölgede orijinal alttürlerin korunmaya alınması gerektiği vurgulanmıştır. Koca (2012), Hatay ve Hakkâri'den aldıkları örnekleri İran ve Kuzey Irak örnekleri ile karşılaştırdığında İran örneklerinin \% 1.7'sinin Doğu ve Güneydoğu Anadolu'dan alınan örnekler ile çakıştığını ortaya koymuştur. Özbakır (2011) ise yaptığı çalışmada Suriye ve İran'dan aldığı örnekleri Hatay, Urfa, Mardin illerinden aldığı örnekler ile karşılaştırmış ve bu illerden alınan örneklerin Suriye'den alınan örneklerle örtüştüğünü bildirmiştir. $\mathrm{Bu}$ çalışma kapsamında Hatay ilinden alınan örneklerin morfometrik analiz sonuçları Özbakır (2011)'ın çalışmasıyla birebir örtüşmüştür. $\mathrm{Bu}$ sonuçlar eski örneklere dayanarak Bodenheimer (1941) tarafindan yapılan Türkiye'nin güneyinde Apis mellifera syriaca bulunduğunu ifade eden bildirişleri destekler niteliktedir. Kandemir ve arkadaşlarının COI ve CtyB genleri ile yaptığı moleküler çalışmada ise Türkiye' nin güneyinden aldıkları örneklerin ise Apis mellifera meda olduğunu bildirmiştir (Kandemir ve ark., 2006a). Bu çalışmanın diskriminant fonksiyon analizinde iki boyutlu kümelenmeler dikkate alındığında sadece Güneydoğu Anadolu Bölgesi'nin diğer bölgelerden ayrılması Türkiye'nin güneydoğusunda kesinlikle farklı bir irk olduğunu kanıtlamaktadır. Fakat morfometrik sonuçlar arasında söz konusu ırkın Apis mellifera syriaca ya da Apis mellifera meda olup olmadığ konusunda çelişkiler bulunmakla birlikte (Ruttner, 1988; Kandemir ve ark., 2000; Siralı ve ark., 2003; Kekeçoğlu, 2007; Koca ve Kandemir, 2013) moleküler teknikler Türkiye'nin güneydoğusunda Apis mellifera meda ırkının varlı̆̆ını güçlendirmektedir. Ancak sınırlar arası arıcıların geçişleri konusunda yasal bir uygulama olmaması bu çelişkinin nedenlerinden biri olabilir. Her ne kadar yazılı kayıtlar olmasa da arıcıların dışardan ana arı satın aldığı ya da ülkemize yakın sınırlar arasında geçişler olduğu bilinmektedir.

Popülasyonları temsil eden gruplara ilişkin bireysel veriler öncelikle ANOVA ile değerlendirilmiştir. 
ANOVA sonuçlarına göre gruplar arası varyasyon değerlendirildiğinde geometrik morfometri yöntemiyle ölçülen koordinatların tamamının önem düzeyi $\mathrm{P}<0.05$ olarak belirlenmiştir. Popülasyonları temsil eden grupların bireysel verileri esas alınarak ölçülen 19 kartezyen koordinata göre MANOVA ile karşılaştırıldığında en az bir koordinat bakımından tüm illerin birbirinden farklılığı önemli bulunmuştur $(\mathrm{P}<0.05)$.

2000 yılında yapılan Türkiye'nin 7 coğrafik bölgesini kapsayan çalışmada Türkiye'de beş farklı rrk olduğu bildirilmiştir. Trakya'da Apis mellifera carnica; Güneydoğu Anadolu'da Apis mellifera meda; Suriye sinırındaki küçük bir bölge (Hatay-Antakya)'de Apis mellifera syriaca; Kuzeydoğu Anadolu'da Apis mellifera caucasica; Ege, Akdeniz, İç Anadolu Bölgeleri ile Karadeniz' in orta ve batı kısımlarında Apis mellifera anatoliaca olduğu bildirilmiştir (Kandemir ve ark., 2000). Koca (2012), Orta Doğu'da yayılış gösteren bal arısı alt türlerini geometrik morfometrik yöntemler ile analiz ederek değerlendirdiği bir çalışmada, Türkiye'den alınan örneklerde Apis mellifera carnica (Trakya) ve Apis mellifera caucasica (Doğu Karadeniz) populasyonlarını ayrı bir grup oluşturduğunu, Apis mellifera anatoliaca (Marmara, Ege, Batı Karadeniz, İç Anadolu) ve Apis mellifera meda (Hatay, Hakkâri, Urfa) örneklerinin birbirine yakın gruplar oluşturduğunu belirtmiştir.

Morfometrik ölçüm yöntemlerine dayanan önceki araştırma sonuçları bu çalışmanın sonuçları ile karşılaştırıldığında Türkiye'nin güneyinde Apis mellifera syriaca bulunduğu söylenebilir. Moleküler tekniklere dayanarak yapılan araştırma sonuçları da bașta Apis mellifera meda olmak üzere Türkiye'nin güneydoğusunda hem Apis mellifera syriaca hem de Apis mellifera meda alt türlerinin bulunduğunu göstermektedir (Palmer ve ark., 2000; Kandemir ve ark., 2000; Kandemir ve ark., 2006a; Kandemir ve ark., 2006b; Adl ve ark., 2007). Bu çalışmada da Akdeniz Bölgesi'nin doğusundan (Kahramanmaraş) alınan örnekler Akdeniz'in geri kalan kesimlerinden ayrı bir grup oluşturmuştur. Bunun yanı sira Güneydoğu Anadolu Bölgesi'nden (Gaziantep) alınan örnekler de ayrı bir grup oluşturmuştur. Dolayısıyla güneyde iki farklı alt tür bulunduğunu bu çalışma sonuçları da destekler niteliktedir.

\section{Sonuç}

Önceki çalışmalarda Anadolu'da 4 alttür ve birçok ekotip olduğu bildirilmiştir (Ruttner; 1988; Smith ve ark., 1997; Palmer ve ark., 2000; Kandemir ve ark., 2006a). Kuzeydoğu Anadolu'da Apis mellifera ucasica, güneyde Apis mellifera meda Anadolu'nun geri kalan kısımlarında ise baskın olarak Apis mellifera anatoliaca olduğu bildirilmiştir (Adam, 1983; Ruttner, 1988; Kandemir ve ark., 2000; Kekeçoğlu, 2007). Settar (1983) yalnızca Ege Bölgesi'nden aldığı örnekler ile yapmış olduğu araştırmalar sonunda Ege Bölgesi'nde bulunan bal arıs1 1rkının Apis mellifera caucasica ve Apis mellifera ligustica arasında bir geçiş popülasyonu olduğunu bildirmiştir. Bu çalışmada Akdeniz’i temsil eden illerin doğu kısmının (Kahramanmaraş) batısından (Hatay, Mersin, Antalya, Isparta) ayrı bir küme oluşturduğu belirlenmiştir. Ege ile Marmara'yı temsil eden illerin grup merkezleri çakışmıştır. Karadeniz (Sakarya, Düzce, Zonguldak, Kastamonu, Sinop, Amasya, Ordu, Trabzon, Artvin) ve Doğu Anadolu Bölgesi (Ardahan, Kars, Iğdır, Van, Hakkâri, Bingöl)'ni temsil eden iller ile Ege ve Marmara'yı temsil eden iller birbirleriyle içe geçmiştir. İç Anadolu örnekleri (Eskişehir, Niğde, Konya, Kırıkkale) bu bölgelere sınırı olan ayr1 bir grup oluşturmuştur. Sonuç olarak bu çalışmanın sonuçları önceki araştırma sonuçlarıyla karşılaştırıldığında Türkiye'nin mevcut biyoçeşitliliğinin kimi lokasyonlar için önceki araştırma sonuçlarıyla çeliştiği yer yer bozulmalar meydana geldiği göze çarpmaktadır. DFA'ne göre çizilen serpilme diyagramında ve UPGMA fenogramındaki gruplanmaların literatür bildirişleri ile çelişmesine karşıllık çapraz doğrulama testinde her bir populasyona ilişkin örneklerin kendi gruplarına doğru sınıflandırılma oranın \% 97.3 oranında yüksek çıkması Türkiye arı biyoçeşitliliğindeki bozulmanın göçer arıcılıktan öte ticari ana arı satışından kaynaklandığını düşündürmektedir. Biyoçeşitlilik ülkelerin milli serveti ve geleceğin güvencesidir. $\mathrm{Bu}$ nedenle ülkemizde bulunan farklı 1rk ve ekotiplerin tanımlanması ve bunların korunması için gerekli önlemlerin alınması gerekmektedir. Türkiye bal arısı ırklarının gen kaynağı olarak korunmasında en önemli aşama popülasyonların genetik yapılarının belirlenmesi ve farklı genetik kompozisyona sahip irk ya da ekotiplerin davranış çalışmalarının yapılması daha sonra da çeşitli karakterler bakımından her bölgeye uyumlu irk ve varyetelerin izole edilmiş lokal bölgelerdeki işletmelerde saf olarak yetiştirilmesi olacaktır.

\section{Teşekkür}

Bu çalışma Düzce Üniversitesi BAP-2015.05.01.318 numaralı Bilimsel Araştırma Projesiyle desteklenmiştir. Makale birinci yazara ait yüksek lisans tezinden üretilmiştir.

\section{Kaynaklar}

Adam, B., 1983. In Search of Best Strains of Honeybees, Second edition, UK: Northern Bee Books.

Adams, D.C., Rohlf, F.J., Slice, D.E., 2004. Geometric morphometrics: Ten years of progress following the 'revolution'. Hystrix, the Italian Journal of Mammalogy, 71(1): 5-16.

Adams, D.C., Rohlf, F.J., Slice, D.E., 2013. A field comes of age: geometric morphometrics in the 21st century. Hystrix, the Italian Journal of Mammalogy; Virtual Morphology and Evolutionary 
Morphometrics in the new millenium, 24(1):7-14.

Adl, M.B.F., Gencer, H.V., Fıratll, Ç., Bahreini, R., 2007. Morphometric characterization of İranian (Apis mellifera meda), Central Anatolian (Apis mellifera anatoliaca) and Caucasian (Apis mellifera caucasica) honey bee population. Journol of Apicultural Research and Bee World, 46(4): 225231.

Anonymous, SPSS for Windows, release15.0 standard version. SPSS Inc., 1989-2004.

Bodenheimer, F.S., 1941. Studies on the honeybee and beekeeping in Turkey. Merkez Ziraat Mücadela Enstitüsü, Birinci bask1, 59s Ankara.

Buttel-Reepen, H., 1906. Beitrage zur Systematic, Biologie, sowie zurgeschichtlichen und Geographischen Verbreitung der Honigbiene (Apis mellifera L), ihrer Varietaten und der übrigen ApisArten. Apistica, 1(1): 118-120.

Çakmak, İ., Fuchs, S., Çakmak, S.S., Koca, A.Ö., Nentchev, P., Kandemir, İ., 2014. Morphometric analysis of honeybees ditributed in northern Turkey along the black sea coast. Uludağ Arıcılık Dergisi, 14(2): 59-68.

Güler, A., Bek, Y., 2002. Forewing angles of honey bee (Apis mellifera) samples from different regions of Turkey. Journal Of Apicultural Research, 41(2): 4349.

Güler, A., Toy, H., 2008. Sinop ili Türkeli yöresi balarıları (Apis mellifera L.)'nın morfolojik özellikleri. OMÜ Ziraat Fakültesi Dergisi, 23(3): 190-197.

Güler, A., Bıyık, S., Güler, M., 2013. Batı Karadeniz Bölgesi balarılarının (Apis mellifera L.) morfolojik karakterizasyonu. Anadolu Journal of Agricultural Sciences, 28(1): 39-46.

Kambur, M., 2017. Türkiye bal arısı (Apis mellifera L.) biyoçeşitliliğinin geometrik morfometrik yöntemler ile belirlenmesi. Yüksek Lisans Tezi. Düzce Üniversitesi, Fen Bilimleri Enstitüsü, 108s, Düzce.

Kandemir, İ., Kence, A., 1995. Allozym variability in a central Anatolian honeybee (Apis mellifera L.) population. Apidologie, 26(1): 503-510.

Kandemir, İ., Kence, M., Kence, A., 2000. Genetic and morphometric variation in honeybee (Apis mellifera) population of Turkey. Apidologie, 31(1): 343-356.

Kandemir, İ., Kence, M., Kence, A., 2005. Morphometric and electrophoretic variation in different honeybees (Apis mellifera) population. Turkish Journal of Veterinary Animal Science, 29(1): 885-890.

Kandemir, İ., Kence, M., Sheppard, W.S., Kence, A., 2006a. Mitochondrial DNA variation in honey bee (Apis mellifera L.) populations from Turkey. Journal of Apicultural Research and Bee World, 45(1): 3338.

Kandemir, İ., Pinto, M.A., Maixner, M., Sheppard, W.S., 2006b. Hinf-I digestion of cytochrome oxidase $I$ region is not a dignostic test for A.m. lamarckii. Genetic and Molecular Biology, 29(4): 747-749.
Kekeçoğlu, M., 2007. Türkiye Balarılarının mtDNA ve Bazı Morfolojik Özellikleri Bakımından Karşılaştırılmasına Yönelik Bir Araştırma. Doktora tezi, Namık Kemal Üniversitesi Zootekni Bölümü, 148s, Tekirdağ.

Kekecoglu, M., Bouga, M., Soysal, M.İ., Harizanis, P., 2009. Genetic divergence and phylogenetic relationships of honey bee populations from Turkey using PCR-RFLP's analysis of two mtDNA segments. Bulgarian Journal of Agricultural Science, 15(6): 589-597.

Kekeçoğlu M., Soysal M.İ., 2010a. Arı Irk ve Ekotiplerinde Biyoçeşitlilik ve Koruma. Ballı Yazılar, Metro Kültür dizisi yayınlar1-4, ss. 128-136.

Kekeçoğlu, M., Soysal, M.İ., 2010b. Genetic Diversity Of Bee Ecotypes in Turkey and evidence for geographical differences. Romanian Biotechnological Letters, 15(5): 5646-5653.

Kence, A., 2006. Türkiye balarılarında genetik çeşitlilik ve korunmasının önemi. Uludağ Arıcılık Dergisi, 1(1): 25-32.

Koca, A.Ö., 2012. Ortadoğu'da Yayılış Gösteren Apis mellifera L. (Hymenoptera: Apidae) Alttürlerinin Geometrik Morfometri Yöntemleriyle Analizi. Doktora tezi. Ankara Üniversitesi Biyoloji Bölümü, $167 \mathrm{~s}$, Ankara.

Koca, A.Ö., Kandemir, İ., 2013. Comparison of two morphometric methods for discriminating honey bee (Apis mellifera L.) populations in Turkey. Turkish Journal of Zoology, 37(2): 205-210.

Maa, T.C., 1953. An inquiry into the systematics of the Tribus Apidini or honeybees (Hymenoptera). Treubia, 21 (1), 525-640.

Özbakır, G.Ö., 2011. Türkiye'nin Güneydoğu Sınırboyu Bal Arıs1 Populasyonlarının (Apis mellifera L.) Morfolojik Özellikleri. Doktora tezi. Ankara Üniversitesi Zootekni Bölümü, 125s, Ankara.

Özdil, F., Yıldız, M.Y., Hall, H.G., 2009. Molecular characterization of Turkish honey bee populations (Apis mellifera) inferred from mitochondrial DNA RFLP and sequence results. Apidologie. 40(1): 570576.

Palmer, M.N., Smith, D.R., Kaftanoglu, O., 2000. Turkish honeybees: Genetic variation and evidence for a fourth lineage of Apis mellifera mtDNA. The Journal of Heredity, 91(1): 42-66.

Ruttner, F., 1988. Biogeography and Taxonomy of Honeybees, 1th ed., 284p, Berlin.

Ruttner, F., 1992. Naturgeschichte der honigbienen. Ehrenwirth Verlag, München, Germany.

Settar, A., 1983. Ege Bölgesi Arı Tipleri Ve Gezginci Arıcılık Üzerine Arastırmalar. Doktora tezi. Ege Ziraai Arastırma Enstitüsü, 129s, İzmir.

Sıralı, R., Şengül, T., Yıldız, İ., 2003. Investigations on some morphological characteristics of the honey bees (Apis mellifera L.) of the Harran plain Turkey. Uludağ Arıcılık Dergisi, 11,(4): 30-36.

Smith, D.R., Slaymaker, A., Palmer M., Kaftanoglu, O., 1997. Turkish honeybees belong to the east 
Mediterrian mitocondrial lineage. Apidologie, 28 (1): 269-274.

Tofilski, A., 2008. Using geometric morphometrics and standard morphometry to discriminate three honeybee subspecies. Apidologie, 39(5). 558-563.
Turan, H., 2011. Trakya Bölgesi Balarısında (Apis mellifera 1.) Geometrik Morfometrik Çalışmalar. Yüksek lisans tezi. Namık Kemal Üniversitesi Zootekni Bölümü, 67s, Tekirdağ. 